M.B. Bello, A. Yusuf,

I.O.O. Amali

Nigeria

\title{
Teachers' Emotional Intelligence and Moral Character as Predictors of Secondary School Students' Moral Character in Ilorin South, Nigeria
}

DOI: 10.15804/tner.2017.47.1.17

\begin{abstract}
This study examines secondary school teachers' level of emotional intelligence and their moral character as predictors of moral character among secondary school students in Ilorin South LGA, Kwara State. 106 teachers and 318 students from 20 secondary schools were purposively sampled for the study. Data collected were analysed using mean-scores, standard-deviation and multiple-regression. The study revealed that secondary school teachers' emotional intelligence predicts secondary school students' moral character. It was recommended that there is a need for teaching emotional intelligence as a foundation course at all the teacher training institutions in Nigeria.
\end{abstract}

Keywords: emotional intelligence, moral character, functionalist theory

\section{Introduction}

In the past few years, parents have questioned the process by which their children acquire moral character, which they exhibit in public. This is because of the depreciating nature of morality in society. It has become a serious problem as anti-social behaviour ranging from indecency, dishonesty, rape, kidnapping, corruption, impatience, to non-caring attitude of both the young and the elderly now prevail in the Nigerian society. The Nigerians are living in a condition where people no longer value what is ideal for society. People have become individualistic 
and materialistic. There are also widespread lawlessness and insecurity to human lives across the country. Society expects the school to help their children become honest, decent, caring persons, who are capable of living good lives in the troubled world (Igbo \& Anugwom, 2002). This has become the concern of educators, sociologists, and psychologists among others, as character development of an individual in society constitutes a critical means for the survival of society as its members learn the differences between right and wrong.

It is on this basis that Lapsley and Narvaez (2006) noted that an individual needs moral virtue in order to do what he/she knows he/she ought to do. As humans, however, we are born with robust moral virtues, which must be developed through interactions that enable us to guide our emotions, thus developing our characters.

The stated goal of moral character development of a nation lies in proper education, training or teaching of its younger generation, in preparing the young to fare better in life. Proper education is not only taking instruction in school subjects, but it should include an understanding of the emotions of the child. Being emotionally intelligent is as important as learning any other subjects. In this study, emotional intelligence means the ability to retain emotional impulses, to read other person's innermost feelings and to handle relationships smoothly (Goleman, 1996). The ability to control impulses is the basis of character. Goleman (1995) says there is an old-fashioned word for the body of skills that emotional intelligence represents: character. Who will, then, take the responsibility for creating a nation whose foundation is character? The simple response is 'the teacher' (Ryan \& Bohlin, 1999). According to Campbell (2003), the teacher is considered to play the central role in cultivating character by inculcating self-discipline and empathy in learners.

Berkowitz and Bier (2004:48) point out that moral character is "an individual's set of psychological characteristics that affect such a person's ability and inclination to function morally". In the same view, Damon (1988) identifies six ways in which social scientists have defined morality: (1) an evaluative orientation that distinguishes good and bad and prescribes good; (2) a sense of obligation toward standards of a social collective; (3) a sense of responsibility for acting out of concern for others; (4) a concern for the rights of others; (5) a commitment to honesty in interpersonal relationships; and (6) a state of mind that causes negative emotional reactions to immoral acts. These are the complete characteristics of a morally sound citizen of a society (Bull, 1973). By implications, the character of a morally sound individual is built on these definitions. How, then, can the teacher help students in the achievement of these? 
In the view of Bastian (2003), the character of an individual is built on emotions. This is because emotions are internal processes possessing a distinctive, individual quality. What makes one distinctly human is one's ability to reason and experience emotions. According to the International Conference on Emotional Intelligence and Leadership (2002), the energy received from emotions helps to "direct, protect or guide" one. Emotions are "messengers" which provide one with information about the outside world (Bull, 1973). There is little wonder that Elisa and Arnold (2006) claimed that an emotionally intelligent teacher will be a better guide for children.

This view lends credence to the study of Walker (2001), whose finding revealed that highly emotionally intelligent teachers display good moral character, and to a large extent influence the moral character of their students. In essence, the greatest asset of a nation's education system would be its emotionally intelligent teachers, who are instrumental to shaping future leaders' moral character. They do this by displaying sound morality to students to emulate and imitate. Highly emotionally intelligent teachers are also considered as very vital to nation building by producing tolerant and more responsible and compassionate future citizens (Berkowitz, 1995).

Emotional intelligence provides the individual with knowledge such as empathy, self-control, stress tolerance, emotional awareness, self-regard, social awareness, self-management, relationship management and social skills needed for moral formation in every individual as well as skills that influence one's ability to succeed in coping with environmental demands and pressure. In essence, emotional intelligence is not considered as the only variable responsible for character formation but the integration of other agents in society. What corroborates this is the research of Bandura (1977 and 1991), which revealed that moral character formation occurs gradually from interaction with the environment, including the application of consequences, the observation of models, and acculturation by social agents. These are what sociologists of education, like Durkheim, Meighan, Blakemore and Cooksey among others, considered as the socialization process.

Similarly, most studies on emotional intelligence basically concern the relationship between academic performance of different classes or groups of people in the school setting. There seem to be few studies on emotional intelligence from the sociological perspective. Thus, it is imperative to conduct this study. 


\section{Purpose of the Study}

The main purpose of this study was to examine teachers' emotional intelligence and their moral character as predictors of secondary school students' moral character. Specifically the study assessed:

a. the level of emotional intelligence of teachers teaching at secondary school.

b. the moral character displayed by secondary school teachers.

c. the moral character displayed by secondary school students.

d. teachers' emotional intelligence and their moral character as predictors of secondary school students' moral character.

\section{Research Questions}

The following research questions were formulated to guide this study.

a. What is the level of emotional intelligence of teachers teaching at secondary school?

b. What are the types of moral character displayed by secondary school teachers in Ilorin South local government?

c. What are the types of moral character displayed by secondary school students?

d. Can teachers' emotional intelligence and their moral character predict secondary school students' moral character.

\section{Research Hypothesis}

$\mathrm{Ho}_{1}$ : Teachers' emotional intelligence and their moral character are not predictors of secondary school students' moral character.

\section{Methodology}

A descriptive survey design was used in this study. The choice of the descriptive survey was in line with the view of Sambo (2008), who maintained that the descriptive survey concerns the gathering of information on people's opinions. The target population for this study comprised Ilorin South secondary school teachers and students. There were 20 secondary schools in Ilorin South Local Government, out of which 15 secondary schools were purposively sampled for the study. 106 teachers and 318 students were sampled from the 15 secondary schools using 
a proportionate sampling technique. The respondents consisted of both male and female teachers and students. The teachers assessed their own level of emotional intelligence, while the moral character they displayed in school was assessed by 318 students (i.e., three students to a teacher, the average sum of three students was used to compute the analysis). The moral character displayed by the students was assessed by their class teachers.

Three questionnaire forms were used to elicit the needed data for this study. The first questionnaire form was a modified four-point Likert scale "Emotional Intelligence Scale," which was adapted from the study of Goldman (1996). Its psychometric properties were content and construct validity and a reliability index of 0.68 . The questionnaire was sub-divided into two sections. Section A dealt with demographic characteristics of the teachers, while section B contained 25 items, which dealt with statements that addressed emotional intelligence. The sub-themes were self-awareness, self-management, social awareness and regulation management.

The second questionnaire form, titled "My Teacher's Assessment Questionnaire (MTAQ)," contained 19 items with psychometric properties of construct validity and the reliability index of 0.60 was adapted by the researchers from the study of Narvaez and Lapsley (2003) to elicit data on the teachers' moral character. Finally, a 25-item questionnaire form, titled "My Students' Assessment Questionnaire (MSAQ)," was adapted from the study of Schonert-Reichl, Lawlor, Oberle \& Thomson (2009), with construct validity and 0.77 reliability index. It was used to collect the needed data from the students on the types of moral character displayed by the teachers. The hypothesis formulated was analyzed using Multiple Regression analysis at the 0.05 level of significance.

\section{Results}

The data collected are presented below.

Research Question 1: What is the level of emotional intelligence of teachers teaching at secondary school?

Table 1. Level of emotional intelligence of secondary school teachers in llorin South

\begin{tabular}{ccc}
\hline Levels of EI & Frequency & Percentage \\
\hline High & 95 & $89.6 \%$ \\
\hline Low & 11 & 10.4 \\
\hline Total & 106 & $100 \%$ \\
\hline
\end{tabular}


This shows that $89.6 \%$ (95) of the teachers have a high level of emotional intelligence while $10.4 \%$ (5) of the teachers have a low level of emotional intelligence. This implies that the secondary school teachers have a high level of emotional intelligence.

Research question 2: What are the types of moral character displayed by Ilorin South teachers?

Table 2. The types of moral character displayed by teachers

\begin{tabular}{|c|c|c|c|c|}
\hline $\mathrm{S} / \mathrm{N}$ & $\begin{array}{c}\text { Statement } \\
\text { My Class teacher: }\end{array}$ & Mean & Std & $\begin{array}{l}\text { Deci- } \\
\text { sion }\end{array}$ \\
\hline 1 & is honest in his / her dealing with students & 3.415 & 0.566 & High \\
\hline 2 & is trustworthy in his /her dealing with students & 3.367 & 0.574 & High \\
\hline 3 & has sound moral character and always stands up for what is right. & 2.971 & 0.668 & High \\
\hline 4 & $\begin{array}{l}\text { is caring/ compassionate/ benevolent to students and everybody } \\
\text { around him/her }\end{array}$ & 3.132 & 0.553 & High \\
\hline 5 & always obeys rules and regulations guiding the school. & 2.981 & 0.850 & High \\
\hline 6 & $\begin{array}{l}\text { always does what is right, even in the face of personal conse- } \\
\text { quences }\end{array}$ & 3.019 & 0.768 & High \\
\hline 7 & $\begin{array}{l}\text { is able to stay calm and rational even under conditions of temp- } \\
\text { tation. }\end{array}$ & 3.141 & 0.668 & High \\
\hline 8 & is just and fair in dealing with students and colleagues at work. & 2.830 & 0.710 & High \\
\hline 9 & always gets on well with students and staff. & 3.122 & 0.580 & High \\
\hline 10 & $\begin{array}{l}\text { never gives up easily; rather he/she keeps trying despite the } \\
\text { hardship to achieve success }\end{array}$ & 3.094 & 0.724 & High \\
\hline 11 & always keeps promises and is reliable & 2.905 & 0.794 & High \\
\hline 12 & $\begin{array}{l}\text { always considers the potentials for physical or emotional harm to } \\
\text { others and avoids such harm. }\end{array}$ & 2.905 & 0.781 & High \\
\hline 13 & $\begin{array}{l}\text { is accountable, dependable, amenable; considers consequences } \\
\text { and accepts responsibility for his/her own actions or inactions; } \\
\text { does not shift blame for his/her own mistakes to others. }\end{array}$ & 2.698 & 0.719 & High \\
\hline 14 & $\begin{array}{l}\text { is able to identify with the feelings of his /her students to better } \\
\text { understand them }\end{array}$ & 2.924 & 0.726 & High \\
\hline 15 & is respectful towards others and students alike & 2.858 & 0.773 & High \\
\hline 16 & is patient when dealing with students and people around him/her & 2.952 & 0.773 & High \\
\hline 17 & forgives when he/she is offended & 3.150 & 0.790 & High \\
\hline 18 & $\begin{array}{l}\text { is ready to seek solutions to problems that will be in everyone's } \\
\text { best interests. }\end{array}$ & 3.415 & 0.782 & High \\
\hline 19 & is a model for life values & 3.367 & 0.743 & High \\
\hline
\end{tabular}


Table 2 shows the mean score of the moral character which the teachers displayed in school with mean scores ranging from 2.60 to 3.14. Since these mean scores are above 2.00 , the acceptable mean score level, it means that the teachers displayed high moral character because they are high in their emotional intelligence.

Research question 3: What are the types of moral character displayed by secondary school students?

Table 3. The type of moral character displayed by secondary school students

\begin{tabular}{clrrc}
\hline S/N & \multicolumn{1}{c}{$\begin{array}{c}\text { Statement } \\
\text { My student : }\end{array}$} & Mean & Std & $\begin{array}{c}\text { Deci- } \\
\text { sion }\end{array}$ \\
\hline 1 & $\begin{array}{l}\text { plays and works cooperatively with other students at the level } \\
\text { his/her age }\end{array}$ & 1.93 & 0.24 & Low \\
\hline 2 & is able to interact with different students & 1.99 & 0.09 & Low \\
\hline 3 & obeys rules and regulations & 1.93 & 0.23 & Low \\
\hline 4 & respects the right of other students & 1.84 & 0.35 & Low \\
\hline 5 & demonstrates self-control & 1.87 & 0.32 & Low \\
\hline 6 & shows self- confidence & 1.98 & 0.13 & Low \\
\hline 7 & demonstrates respect for adults and other students in the school & 1.95 & 0.21 & Low \\
\hline 8 & accepts responsibility for actions & 1.94 & 0.23 & Low \\
\hline 9 & listens attentively during lessons & 2.00 & 0.00 & High \\
\hline 10 & follows directions diligently in the school & 1.94 & 0.23 & Low \\
\hline 11 & works independently & 1.34 & 0.39 & Low \\
\hline 12 & takes care of school properties & 2.08 & 0.41 & High \\
\hline 13 & is able to solve day-to-day problems by him/herself & 2.30 & 0.55 & High \\
\hline 14 & is able to adjust to changes in routine & 1.60 & 0.42 & Low \\
\hline 15 & is able to follow class routines without reminders & 1.90 & 0.29 & Low \\
\hline 16 & shows tolerance to friends and mates & 1.80 & 0.40 & Low \\
\hline 17 & tries to help someone who is being hurt & 2.14 & 0.92 & High \\
\hline 18 & tries as much as possible to settle disputes among friends & 1.02 & 0.09 & Low \\
\hline 19 & offers help to other students who have difficulty with a task & 2.12 & 0.67 & High \\
\hline 20 & does not always get into physical fight & 1.63 & 0.45 & Low \\
\hline 21 & takes things that do not belong to him/her & 1.78 & 0.26 & High \\
\hline 22 & laughs at other student's discomfort & 0.22 & Low \\
\hline 23 & is disobedient & 1.70 & 0.51 & Low \\
\hline 24 & bullies mates and other junior students in the school. & & \\
\hline & & & & \\
\hline
\end{tabular}


25 if there is a quarrel or dispute among friends he/she tries to $\begin{array}{lll}1.66 & 0.21 \quad \text { Low }\end{array}$ settle it

Table 3 shows that 14 items out of the 25 items in the questionnaire fall within the mean score of 1.02 to 1.99 , which is less than the accepted mean score of 2.00 . By implication, dishonesty, bullying of mates and other junior students, trying as much as possible to settle disputes among friends and being able to interact well with other students, among other things, are some types of moral character that the students least displayed.

\section{Hypothesis Testing}

$\mathrm{Ho}_{1}$ Teachers' emotional intelligence and their moral character are not a determinant of secondary school students' moral character.

Table 4. The predicted level of independent variable over the dependent one

\begin{tabular}{lcccccr}
\hline \multicolumn{1}{c}{ Model } & Sum of Square & df & Mean Square & F & Sig. & Decision \\
\hline Regression & 50.47 & 2 & 25.23 & 3.20 & 0.045 & Rejected \\
\hline Residual & 811.26 & 103 & 7.87 & & & \\
\hline Total & 861.73 & 105 & & & & \\
\hline
\end{tabular}

$\mathrm{P}=0.05$

Table 4 shows that the calculated F-value is 3.20 while the significant probability value of 0.045 is less than the alpha value of 0.05 . Since the probability value is lower than the alpha value, the null hypothesis is not accepted. By implication, teachers' emotional intelligence and their moral character can predict the moral character of secondary school students.

Table 5. Model summary

\begin{tabular}{ccccc}
\hline Model & R & R Square & Adjusted R. Square & Std. Error Estimate \\
\hline & 0.24 & 0.059 & 0.040 & 2.806 \\
\hline
\end{tabular}

Table 5 shows the independent variables (teachers' emotional intelligence and teachers' moral character), which are very small as they contribute to R-Square of $0.059(5.9 \%)$ to the model (student moral character). To ascertain the contri- 
butions of each independent variable, Beta and t-value were computed and the results are presented in the table below.

Table 6. Beta weight and t-value of the three variables

\begin{tabular}{lllllr}
\hline \multicolumn{1}{c}{ Model } & \multicolumn{1}{c}{ B } & Std. Error & Beta & T & Sig \\
\hline Students' & 46.371 & 4.205 & & 11.02 & .000 \\
\hline emotional intelligence & .088 & .040 & .210 & 2.17 & .032 \\
\hline Teachers' moral character & -.037 & .038 & -.094 & -.97 & .334 \\
\hline
\end{tabular}

The computation revealed that the teachers' emotional intelligence contributed to the Beta weight of 0.210 and $t$-value of 2, while the teachers' moral character Beta weight is 0.094 and the $t$-value is .971. This implies that emotional intelligence is the most significant variable that serves as a predictor of students' moral character while teachers' moral character is a negative predictor.

Figure 1. Summarizes the findings:
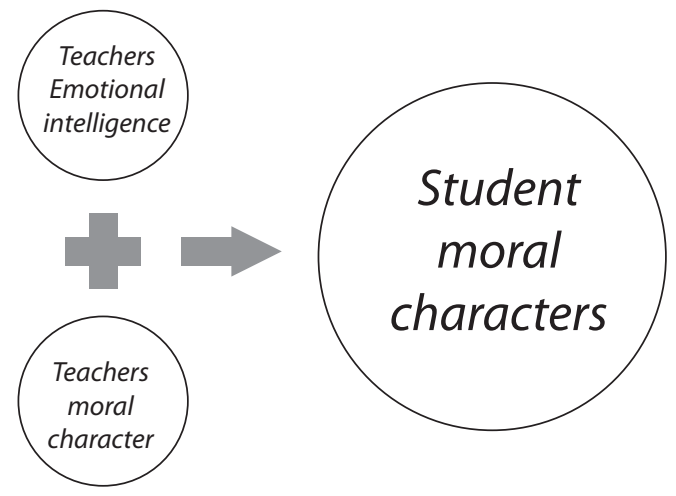

Figure 1. Model of relationship between teachers' El and moral character predicting students' moral character

\section{Discussion}

A lot of research has been carried out on the emotional aspect of education in recent years. Working on the emotions for positive gain and encouraging emotional growth of moral character in children's classroom has become more 
crucial now than before. This is due to the social problems prevailing in society. The presented study has revealed that a highly emotional intelligent teacher with adequate moral character can predict the student's moral character. In essence, the teacher can serve as a role model for students to emulate in order to develop good moral character. This is what every member of society expects from the school through the teachers that train the students in the act of developing moral character. The teacher is expected to serve as a role model for students to emulate in the formation of sound and effective moral character. This is possible only if teachers possess a high level of emotional intelligence, which can offer them the opportunity to display sound moral character worth emulating by their students.

This finding is in agreement with micro-functionalists, whose basic principle sees emotional intelligence as a messenger that provides an individual with information which can direct their action. By implication, teachers' emotional intelligence sends information through the kind of character that the teachers display in terms of either good or bad. In line with the three components of micro-functionalists, teachers are able to recognize their emotional state through their awareness, recognition and understanding of themselves. This helps them in the manifestation of the different moral character which they display in society. The kind of moral character which they display sends a strong message or information to their students on which type of moral character they can also display to society.

What also supports this finding is the study of Bandura (1977 \& 1991), which reveals that moral character formation in students can occur gradually from interactions with the environment, observation of role models (i.e., the teachers in the school), and acculturation by social agents.

\section{Recommendations and Conclusion}

The following recommendations are provided based on the findings:

a. Secondary school teachers' emotional intelligence should be properly developed to enhance positive character formation so as to be able to influence their students' moral character positively.

b. Attention needs to be paid to the development of secondary school students' emotional intelligence.

c. There is a need for the teaching of emotional intelligence as a foundation course at all levels of pre-service teacher training in teacher training institutions in Nigeria. 
In conclusion, education contributes to the natural and harmonious development of an individual. The main aim of education is the all-round holistic development of students. The teacher is the central figure in the educational process, who helps in making an individual a better person. Teachers with high emotional intelligence display good moral character, which they can teach their students. They can help their students to learn what their values are, to believe in these values as an integral part of who they are so that they can live their lives in alignment with these values. Teachers can play an essential role in helping students learn and apply a moral-reasoning process. The teacher makes a difference. It is the teacher who moulds the most precious material of the land (young generation) in their most impressionable period of development. In order for the teacher to do this, he/she must possess the skills, emotional intelligence, personality traits and moral character that would serve as a determinant of students' moral character.

\section{References}

Bandura, A. (1977). Self-efficacy: Toward a unified theory of behavioral change. Psychological Review, 84, 191-215.

Bastian, V.A., Burns, N.R., \& Nettelbeck, T. (2005). Emotional intelligence predicts life skills, but not as well as personality and cognitive abilities. Personality and Individual Differences,39(6), 1135-1145. http://dx.doi.org/10.1016/j.paid.2005.04.006

Berkowitz, M. \& Bier, M. (2004). Research-based character education. Annals of the American Academy of Political and Social Sciences.

Berkowitz, M.W. (1995). The education of the complete moral person. Aberdeen: Gordern Cook Foundation.

Campbell, E. (2003). The ethical teacher. New York: Open University Press.

Edannur, S. (2010). Emotional Intelligence of Teacher Educators. International Journal Education Sciences, 2, 2, 115-121.

Elias M.J., Arnold H. (2006) .Emotional Intelligence and Academic Achievement. Social emotional Learning in the Classroom. California: Corwin Press, Thousand oaks: Sage Publications.

Kallen, H. (1931). Functionalism in Encyclopedia of the Social Sciences. $6^{\text {th }}$ Edition. New York: Macmillan.

Goleman, D. (2001). Emotional intelligence: Issues in paradigm building. Consortium for research on emotional intelligence in organisations. Retrieved from: http://www. eiconsortium.org/

Goleman, D. (1996). Emotional intelligence: why it can matter more than IQ. New Bantam. Goodlad, J. (1992). The moral dimension of schooling and teacher education. Journal of Moral Education, 21,2, 87-98. 
Igbo, I. \& Anugwom, S.O. (2002). The history of character education. Journal of Physical Education, Recreation and Dance, 68, 9, 35-37.

International Conference on Emotional Intelligence and Leadership (2002). The concept of emotional intelligence. Retrieved from: www.emotional-org/34/nut.htm

Kochanska, G. (1997). Emotion, regulation, and moral development. Annual review of psychology. Retrieved from: www.annualreviews.org

Lapsley, D. K., \& Narvaez, D. (2006). Character education. In W. Damon \& R. Lerner, (Eds.), Handbook of child psychology (Vol. 4). New York: Wiley.

Lewis, M. \& Haviland-Jones, J. (eds.) 2000. Handbook of emotions. $2^{\text {nd }}$ edition. New York: Guilford.

Martindale, D. (1970). The nature and types of sociological theory. London: Lowe and Brydone Printers Ltd.

Mayer, J. \& Perkins, D. \& Caruso, D. \& Salovey, P. (2001). Emotional Intelligence and giftedness. Roeper Review, 23, 3, 131-137.

Mayer, J. \& Salovey, P. \& Caruso, D. \& Sitarenios, G. (2001). Emotional Intelligence as a standard intelligence. Emotion, 1, 3, 232-242.

Narvaez, D. \& Lapsley, D.K. (2003). Teaching for moral character: The strategies for teacher education. Journal of Teacher Education.2,4,2-10.

Narvaez, D., \& Rest J. P. (1995). The four components of acting morally. In W. Kurtines \& J. Gewirtz (Eds.), Moral behavior and moral development: An introduction (pp. 385-400). New York: McGraw-Hill.

The Research Advisors(2006). Sample size table. Retrieved from: http://research-advisors. com.

Ryan, K., \& Bohlin, K. (1999). Building character in schools. San Francisco: Jossey-Bass.

Sambo, A. A. (2008). Research methods in education. Edo: Stirling-Horden Publishers.

Schonert-Reichl, K.A, Lawlor, S.M, Oberle, E. \& Thomson, K. (2009). Identifying Indicators and Tools for Measuring Social and Emotional Healthy Living: Children Ages 5-12 Years. Retrieved from: www.phac-aspc.gc.ca

Solomon, D., Watson, M., \& Battistich, V. (2001). Teaching and schooling effects on moral/ pro-social development. In V. Richardson (Ed.), Handbook of research on teaching ( $4^{\text {th }}$ ed.) (566-603). Washington, DC: Association for Supervision and Curriculum Development.

Ujo, A. A. (2000). Social research: a non- quantitative approach. Nigeria: Anyaotu Enterprise and Publisher Ltd. 